University of Nebraska - Lincoln

DigitalCommons@University of Nebraska - Lincoln

U.S. Environmental Protection Agency Papers

U.S. Environmental Protection Agency

2006

Changes in manganese and lead in the environment and young children associated with the introduction of methylcyclopentadienyl manganese tricarbonyl in gasoline-preliminary results

\author{
Brian Gulson \\ Graduate School of the Environment, Macquarie University, Sydney NSW 2109, Australia \\ Karen Mizon \\ Graduate School of the Environment, Macquarie University, Sydney NSW 2109, Australia \\ Alan Taylor \\ Department of Psychology, Macquarie University, Sydney NSW 2109, Australia \\ Michael Korsch \\ Commonwealth Scientific and Industrial Research Organisation(CSIRO)/Exploration \& Mining, Sydney, \\ Australia \\ Jennifer Stauber \\ CSIRO/Energy Technology, Sydney, Australia

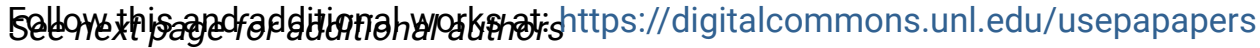 \\ Part of the Civil and Environmental Engineering Commons
}

Gulson, Brian; Mizon, Karen; Taylor, Alan; Korsch, Michael; Stauber, Jennifer; Davis, J. Michael; Louis, Honway; Wu, Michael; and Swan, Hilton, "Changes in manganese and lead in the environment and young children associated with the introduction of methylcyclopentadienyl manganese tricarbonyl in gasoline-preliminary results" (2006). U.S. Environmental Protection Agency Papers. 6.

https://digitalcommons.unl.edu/usepapapers/6

This Article is brought to you for free and open access by the U.S. Environmental Protection Agency at DigitalCommons@University of Nebraska - Lincoln. It has been accepted for inclusion in U.S. Environmental Protection Agency Papers by an authorized administrator of DigitalCommons@University of Nebraska - Lincoln. 


\section{Authors}

Brian Gulson, Karen Mizon, Alan Taylor, Michael Korsch, Jennifer Stauber, J. Michael Davis, Honway Louis, Michael Wu, and Hilton Swan 


\title{
Changes in manganese and lead in the environment and young children associated with the introduction of methylcyclopentadienyl manganese tricarbonyl in gasoline - preliminary results
}

\author{
Brian Gulson ${ }^{\mathrm{a}, \mathrm{b}, *}$, Karen Mizon ${ }^{\mathrm{a}}$, Alan Taylor ${ }^{\mathrm{c}}$, Michael Korsch $^{\mathrm{b}}$, Jennifer Stauber ${ }^{\mathrm{d}}$, \\ J. Michael Davis ${ }^{\mathrm{e}}$, Honway Louie ${ }^{\mathrm{f}}$, Michael $\mathrm{Wu}^{\mathrm{f}}$, Hilton Swan ${ }^{\mathrm{f}}$ \\ ${ }^{a}$ Graduate School of the Environment, Macquarie University, Sydney NSW 2109, Australia \\ ${ }^{\mathrm{b}}$ Commonwealth Scientific and Industrial Research Organisation(CSIRO)/Exploration \& Mining, Sydney, Australia \\ ${ }^{\mathrm{c}}$ Department of Psychology, Macquarie University, Sydney NSW 2109, Australia \\ ${ }^{\mathrm{d}}$ CSIRO/Energy Technology, Sydney, Australia \\ ${ }^{\mathrm{e}} U S$ EPA, Research Triangle Park, NC, USA \\ ${ }^{\mathrm{f}}$ Australian Government Analytical Laboratories, Sydney, Australia
}

Received 27 October 2004; received in revised form 8 March 2005; accepted 17 March 2005

Available online 5 May 2005

\begin{abstract}
A 4-year longitudinal study is being conducted to evaluate potential changes to the environment and exposure of young children associated with the introduction of methylcyclopentadienyl manganese tricarbonyl (MMT) into Australia in 2001. The cohort consists of 57 females and 56 males, with an age range of 0.29-3.9 years. Samples are collected every 6 months from children in residences located at varying distances from major traffic thoroughfares in Sydney. Environmental samples include air, house, and daycare center dustfall, soil, dust sweepings, and gasoline; samples from the children include blood, urine, handwipes prior to and after playing outdoors, and a 6-day duplicate diet. All samples are analyzed for a suite of 20 elements using inductively coupled plasma methods. Results are presented for the first three 6-month sampling periods for lead (Pb) and manganese (Mn). For dustfall accumulation, expressed as metal concentration $/ \mathrm{m}^{2} / 30$ days, there was no significant difference between homes and daycare centers for either $\mathrm{Pb}$ or $\mathrm{Mn}$, no significant change over the three sampling periods (time) for $\mathrm{Pb}$ or $\mathrm{Mn}$, and a positive relationship between "traffic exposure" (traffic volume and proximity to the road) and $\mathrm{Pb}$ but not $\mathrm{Mn}$. Lead concentrations in soil was a significant predictor for $\mathrm{Pb}$ in the house dustfall. For handwipes, the concentrations of $\mathrm{Pb}$ and $\mathrm{Mn}$ in wipes taken from children after playing outdoors was usually significantly greater than those for wipes taken prior to playing. There was no significant association between the concentrations of either $\mathrm{Pb}$ or $\mathrm{Mn}$ in handwipes and traffic exposure, and there was no significant association between $\mathrm{Pb}$ concentrations in the handwipes and gender, although the latter showed a marginally significant association for Mn $(P=0.053)$. Age was related to $\mathrm{Pb}$ level in the handwipes, with older subjects having higher $\mathrm{Pb}$ levels, and there were significant decreases in $\mathrm{Pb}$ and $\mathrm{Mn}$ concentrations over time. Dustfall accumulation was a significant predictor for $\mathrm{Pb}$ in the handwipes, and dust sweepings were a significant predictor of $\mathrm{Mn}$ in handwipes. Blood lead $(\mathrm{PbB})$ concentrations ranged from 0.6 to $19 \mu \mathrm{g} / \mathrm{dL}(\mathrm{GM} 2.6)(n=269)$, and manganese in blood (MnB) ranged from 1.8 to $45 \mu \mathrm{g} / \mathrm{L}(\mathrm{GM} 11.6)(n=254)$. There was no significant difference between females and males for either mean $\mathrm{PbB}$ or $\mathrm{MnB}$; over time there was a significant decline in $\mathrm{PbB}$ but no significant change in MnB. The only significant predictor for $\mathrm{PbB}$ was dustfall accumulation, although dietary intake may also be important, and the only significant predictor for $\mathrm{MnB}$ was $\mathrm{Mn}$ in handwipes prior to playing. At this early stage of the investigation we have not been able to
\end{abstract}

\footnotetext{
${ }^{*}$ Corresponding author. Graduate School of the Environment, Macquarie University, Sydney NSW 2109, Australia. Fax: +61 298507972.

E-mail address: bgulson@gse.mq.edu.au (B. Gulson).
} 
detect any increases in $\mathrm{Mn}$ in these environmental samples or blood samples potentially associated with the use of MMT; in fact the Mn levels in handwipes declined over time.

(C) 2005 Elsevier Inc. All rights reserved.

Keywords: Manganese; MMT; Lead; Young children; Blood; House dust; Soil; Handwipes

\section{Introduction}

Motor vehicles are a ubiquitous source of airborne emissions that can potentially result in widespread contamination of the environment and have direct and indirect impacts on human health, especially that of young children. Two metals of specific concern in motor vehicle emissions are lead $(\mathrm{Pb})$ and manganese $(\mathrm{Mn})$. Lead was first added to gasoline as tetraethyl lead (TEL) in the 1920s. Although subsequently used worldwide, the use of $\mathrm{Pb}$ in gasoline has been phased out in recent years or is in the process of being phased out in many countries. The Ethyl Corp., a major manufacturer of TEL, also developed the octane enhancer methylcyclopentadienyl manganese tricarbonyl (MMT) in the 1950s and as of 2003 was marketing the additive in 30 countries (Ethyl Corp., 2003).

Although both TEL and MMT are organometallic compounds, combustion of fuel mixtures containing these additives produces particulate matter comprising inorganic compounds of the respective metals. Emission of these particles in vehicle exhaust results in their wide dispersion through the environment and exposure of human populations. The decline in $\mathrm{Pb}$ exposure levels associated with reductions of $\mathrm{Pb}$ in gasoline has been well documented in various countries (e.g., Thomas et al., 1999; Monna et al., 1997; De Miguel et al., 1997; Rodamilans et al., 1996; von Storch et al., 2003; Widory et al., 2004). A similar potential for environmental dispersion of particulate $\mathrm{Mn}$ compounds and consequent human exposure to $\mathrm{Mn}$ in relation to the use of MMT in gasoline has been anticipated and is a topic of ongoing scrutiny by public health agencies (Davis, 1998).

The health effects of $\mathrm{Pb}$ and $\mathrm{Mn}$ have been the subject of numerous research studies, both experimental and epidemiological. For $\mathrm{Pb}$, the concentration of $\mathrm{Pb}$ in blood $(\mathrm{PbB})$ has provided a widely accepted index of exposure-dose that has been correlated with various health endpoints. For example, in 1986 the US Environmental Protection Agency (EPA) concluded that a PbB level of " $10 \mu \mathrm{g} / \mathrm{dL}$ and possibly lower" constituted a level of concern for adverse effects on children's neurobehavioral development, based on findings from several prospective epidemiological studies (US EPA, 1986, 1990). This conclusion was independently affirmed and extended by several other public health agencies, including the World Health Organization (WHO, 1995), and has served as a basis for extensive efforts worldwide to reduce lead exposure through all environmental media and pathways (e.g., Davis and Grant, 2003).

Although not as extensive as that for $\mathrm{Pb}$, a substantial database of information on the health effects of $\mathrm{Mn}$ exists (ATSDR, 2000), and from this information it has been possible to characterize concentration-effect relationships for Mn. For example, the US EPA identified $0.050 \mu \mathrm{g} \mathrm{Mn} / \mathrm{m}^{3}$ as an inhalation reference concentration (RfC), which is an estimate (with uncertainty spanning about an order of magnitude) of a continuous inhalation exposure level for the human population (including sensitive subpopulations) that is likely to be without appreciable risk of deleterious noncancer effects during a lifetime (US EPA, 1993). However, key uncertainties are inherent in the Mn RfC because of incomplete information and extrapolations that had to be used in deriving this value. Furthermore, a generally accepted bioindicator of $\mathrm{Mn}$ exposure and uptake comparable to $\mathrm{PbB}$ has not emerged to date (Davis, 2001). In contrast to $\mathrm{Pb}$ which resides dominantly $(>96 \%)$ in the erythrocytes in whole blood, $\sim 66 \%$ of $\mathrm{Mn}$ resides in the erythrocytes (Alarcon et al., 1996). Thus, much remains to be done to better characterize Mn exposure and potential health risks.

The need for better information on Mn exposure and health effects has been especially evident in connection with attempts to assess the potential public health impacts of MMT in fuel. One of the most intensive efforts in this regard was conducted by EPA (US EPA, 1994) in response to a petition from the Ethyl Corp. to allow the use of MMT in the United States. The assessment of health risks requires information on exposure potential and qualitative and quantitative toxicity characteristics. For the MMT assessment (US EPA, 1994), adequate data on Mn exposure directly related to MMT were not available, and thus it was necessary to construct estimates of potential exposure using several inferential arguments and assumptions (Davis et al., 1998).

Although MMT had been used in US gasoline to a limited extent during the 1970s and 1980s, a better opportunity to examine personal exposure to $\mathrm{Mn}$ in relation to MMT existed in Canada, where MMT had been used extensively since the 1970 s to the present (Zayed, 2001; Health Canada, 2003). Following a recommendation from EPA (US EPA, 1991), the Ethyl Corp. funded a study to measure Mn exposure levels of a probabilistic sample of Toronto residents (Pellizzari 
et al., 1999). The results of this study and related analyses funded by Ethyl Corp. (Clayton et al., 1999; Crump, 2000) suggest that $\mathrm{Mn}$ exposure levels are generally below the RfC of $0.050 \mu \mathrm{g} / \mathrm{m}^{3}$, with a median concentration of $0.008 \mu \mathrm{g} / \mathrm{m}^{3}$ for personal samplers. The Toronto study and related work are currently under evaluation by the US EPA for their implications for potential Mn exposure levels in US cities with meteorological, traffic, and other conditions that may differ from Toronto (Davis, 2004).

The Ethyl Corp. also funded a Mn exposure study in Indianapolis, Indiana, where MMT has not been used (Pellizzari et al., 2001). An objective of this study was to characterize Mn exposure levels "both before and after MMT was introduced into gasoline in the US." However, use of MMT in the United States has been quite limited to date, and thus it remains to be seen whether or when conditions will exist to allow the second phase of this study.

The impact of $\mathrm{Mn}$ on the environment and humans resulting from the introduction of MMT is controversial. From an environmental point of view, Bhuie and Roy (2001) analyzed surface soil samples $(0-5 \mathrm{~cm}$ depth) at distances of up to $40 \mathrm{~m}$ from the roadside in the Greater Toronto Area Canada for a suite of elements, including total and available Mn plus a number of other parameters. They concluded that, although MMT has been used continuously for approximately 25 years in Canada, its contribution to the terrestrial environment has been very low and has not significantly increased Mn levels along the highways. In contrast Mielke et al. (2002) estimated that at 1999 US highway fuel use, $8.3 \mathrm{mg} \mathrm{Mn} / \mathrm{L}$ would yield 5000 metric tons of $\mathrm{Mn}$ annually. If $13 \%$ of $\mathrm{Mn}$ were emitted via the exhaust system, 650 tons $\mathrm{Mn}$ would become aerosols annually, while $87 \%$ or 4350 tons remained in engines. A precautionary lesson from the use of $\mathrm{Pb}$ as a fuel additive is that the use of $\mathrm{Mn}$ as a fuel additive would be associated with an increased risk for neonates exceeding the estimated total daily intake of 2.1-16.5 $\mu \mathrm{g}$ $\mathrm{Mn}$ (especially in urban inner-city environments) because neonates lack fully functional hepatic clearance for $\mathrm{Mn}$.

The Australian Government phased out the use of lead in gasoline in 2002 (NICNAS, 2003). To facilitate the transition to lead-free gasoline, the government is allowing MMT to be used as a substitute for $\mathrm{Pb}$ for a limited period. The recent introduction of MMT to Australian gasoline as an antivalve recession additive has therefore presented an opportunity to measure changes in environmental $\mathrm{Mn}$ concentrations and indicators of $\mathrm{Mn}$ exposure in children, a population of special concern. The present study was initiated to take advantage of this opportunity, with the expectation of making repeated measurements over at least a 4-year period.
Given the lack of a single definitive bioindicator of $\mathrm{Mn}$ exposure-dose, several measures of $\mathrm{Mn}$ have been selected for the purposes of this long-term study. Environmental measurements of $\mathrm{Mn}, \mathrm{Pb}$, and several metals are being made for air, house-interior dustfall, exterior dust sweepings, soil, and water. Samples are being collected from residences at varying distances from major traffic thoroughfares in Sydney, New South Wales and in the surrounding suburbs. In addition, the concentrations of $\mathrm{Mn}, \mathrm{Pb}$, and other metals are being measured in blood, urine, handwipes, and duplicate diet samples for children 6-18 months of age residing at various proximities to major thoroughfares in the Sydney metropolitan area. This paper reports initial results for $\mathrm{Pb}$ and $\mathrm{Mn}$ in house dustfall, handwipes, and blood collected over three 6-month cycles, i.e., an 18month period.

\section{Materials and methods}

\subsection{Subjects}

The cohort consisted of 57 females and 56 males whose ages ranged at the first data collection from 0.29 to 2.4 years with a mean of 1.3 years. Recruitment of subjects has been by approaches to parents with assistance for introduction from the Play Group Association of NSW, the LEAD Group, Early Childhood Centres of NSW, Long Day Child Care Centres, advertising, and an article about the study in the widely distributed free magazine "Sydney's Child." Selection criteria were that the children (1) were approximately 6-18 months of age, (2) lived within varying distances from major traffic thoroughfares with the main focus on those that lived within $100 \mathrm{~m}$, (3) resided in a home distant from any known $\mathrm{Mn}$ and $\mathrm{Pb}$ source such as a ferro-alloy industry or railways, and (4) had parents who where not engaged in such industries.

Initially it was hoped to stratify the cohort into those who lived within $100 \mathrm{~m}$ of the main thoroughfares and recruit a separate control group who lived in low-traffic areas, possibly from a township outside Sydney. Despite attempts to recruit such a control group, this proved impossible. Thus, each subject was assigned a "traffic exposure" rating from 1 (low) to 5 (high) based on residence distance from the roads and traffic density on the respective roads. Daily traffic flow information was obtained from the NSW Roads and Traffic Authority database and flows range up to 80,000 vehicles per day.

\subsection{Sampling}

Sampling has been generally undertaken on 6-month cycles with the first samplings of 37 subjects undertaken $\sim 5-7$ months after the introduction of MMT. As this is 
an ongoing longitudinal study, at the time of writing, observations for four or more time points were available for only a relatively small number of subjects, so the analyses reported here are based on data for the first three sampling times.

Initially, samples of all gasoline brands were collected in glass containers and analyzed for a multielement suite to determine the presence of Mn (indicative of MMT) and for any "pathfinder" elements in addition to Mn. Now gasoline samples are collected in aluminum fuel containers, preleached for $24 \mathrm{~h}$ in dilute clean hydrochloric acid to remove any $\mathrm{Mn}$. As some companies have contemplated using MMT in diesel fuel (P. Nelson, pers. commun., 2003), diesel was also analyzed from September 2003. At this stage, no MMT has been detected in diesel of the major fuel suppliers.

Soil samples and exterior dust sweepings (using dust pan and broom over $\sim 1 \mathrm{~m}^{2}$ ) from front and back areas around the houses were collected in zip-lock plastic bags at 6-monthly intervals to provide information on current deposition.

Duplicates of the children's dietary intakes for 6 days were obtained during the same time periods as those of the environmental sampling. Drinking water samples, as part of the dietary intake, were collected on the same occasions. The protocols for sample collection and preparation are described in Gulson et al. (1997).

Handwipes for each hand of the children were collected into cleaned polyethylene centrifuge test tubes prior to, and after, the child played outdoors. Both hands front and back and each finger were wiped individually using a "Johnson \& Johnson" baby wipe. The dataset contained 453 observations for 114 subjects, a mean of 4.1 observations per subject. Wipe $1(n=114$ subjects) refers to handwipes of children prior to playing outdoors and wipe 2 ( $n=99$ subjects) to wipes taken after playing outdoors for varying periods of time, usually about $1 \mathrm{~h}$. The second wipe protocol was not instigated until the second sampling period.

Dustfall accumulation in two frequented areas of the house (child's bedroom, living/play room) were collected over 6-month periods by the petri dish method (Gulson et al., 1995) to provide ongoing monitoring of dust $\mathrm{Mn}$ and other metal loadings (expressed as amount of metal/ area/time). When the child spent time at a childcare center, the dust accumulation was monitored at that center for the same duration as that for the home. The data set contained 270 observations for 98 subjects, with a mean of 2.7 observations per subject and a range of 1-6. There were data from both home and childcare locations for 42 of the subjects and for home only for 56 of the subjects.

Venous blood samples were collected by a trained phlebotomist into ultra-trace-metal-free Vacutainer tubes using a $23 \mathrm{G} \frac{3}{4}$ Vacutainer blood collection set consisting of 12-in tubing with multiple sample Luer adapter ("butterfly"). The child's weight at each visit was measured using portable electronic scales.

\subsection{Sample preparation and analysis}

Soil samples were dried in an oven at $20^{\circ} \mathrm{C}$ and then sieved through nylon passing 1-mm particles. Obvious extraneous material such as hair and vegetation were removed from the dust sweepings. Dust from the petri dishes was transferred to cleaned analysis tubes using $50 \%$ ultraclean nitric acid and diluted to a 5\% solution with clean water. The remainder of the sample preparation was carried out in clean laboratories at Australian Government Analytical Laboratories in Sydney.

A 1-mL sample of blood was digested in $2 \mathrm{~mL}$ Suprapur nitric acid $\left(\mathrm{HNO}_{3}\right)$ for $1 \mathrm{~h}$, with ultraclean water (MilliQ) subsequently added to make a $20-\mathrm{mL}$ solution for analysis. High-resolution inductively coupled plasma mass spectrometry (ICP-MS) was used to measure $\mathrm{Cr}, \mathrm{Cu}, \mathrm{Fe}, \mathrm{Mn}, \mathrm{Ni}, \mathrm{V}$, and $\mathrm{Zn}$; other metals were measured by ICP-MS/inductively coupled plasma atomic emission spectroscopy (ICP-AES).

A 2-mL sample of urine was digested in $3 \mathrm{~mL} \mathrm{HNO}_{3}$, with water then added to make a $30 \mathrm{~mL}$ solution, and heated for $1 \mathrm{~h}$. Metals were analyzed as for blood.

One-gram samples of soil/dust sweepings and dustfall accumulation were digested first with $3 \mathrm{~mL} \mathrm{HNO}_{3}$, and second with $3 \mathrm{~mL} \mathrm{HCL}$ at $95-98^{\circ} \mathrm{C}$ for $2 \mathrm{~h}$. Water was added to make up a $40-\mathrm{mL}$ solution; $0.5 \mathrm{~mL}$ of the digest solution was taken and made up to $10 \mathrm{~mL}$. Metals were determined by ICP-MS/ICP-AES as for blood.

Each handwipe was digested in $15 \mathrm{~mL} \mathrm{HNO}_{3}$, made up to a $50-\mathrm{mL}$ solution; $2 \mathrm{~mL}$ of the digest solution was taken and then made up to $10 \mathrm{~mL}$. Metals were determined by ICP-MS/ICP-AES as for blood.

Speciation and quantification of MMT, $\mathrm{Mn}$, and $\mathrm{Pb}$ in the most popular brands of unleaded and leadreplacement gasoline were undertaken using gas chromatography atomic emission spectroscopy (Swan, 1999).

\subsection{Statistical analysis}

A mixed-model analysis (SPSS version 12.0) was used to study the relationship between the concentration of each metal and each of the following: time in months since the first collection, category of traffic exposure (centered at the mean), gender, age (at first collection, centered at the mean), and location within the house (for petri dusts). Subjects were treated as a random factor. The study contained several pairs of twin subjects; each pair was treated as a single cluster in the mixed analysis. Time, which was coded zero for the first collection, was treated as a continuous rather than a categorical variable because the intervals between collections were not uniform. The use of the mixed model made it 
possible to take into account, and assess the dependencies between the multiple observations for each subject and to obtain efficient estimates of the parameters despite the unbalanced nature of the data (unequal numbers of observations for different subjects). The variables were coded in such a way that the intercept in the reported results shows the mean of the transformed metal level for a male with wipe type 1 (collected prior to playing outside) at the mean age of first collection and the mean risk level. That is, gender and wipe type were indicator- or dummy-coded, with males and wipe type 1 as the reference or zero-coded category, and age of first collection and risk level were centered at their means.

Supplementary analyses were carried out to assess the relationships between blood (as the dependent variable) and environmental samples of handwipes, petri dust, dust sweepings, soil, and diet (as the independent variables) and between handwipes (dependent variable) and petri dust, dust sweepings, soil, and diet. For these analyses the data were aggregated over time, so that subject, rather than each individual measurement, was the unit of analysis. This aggregation, which was necessary because different types of measurement were made at different times, meant that the aggregated observations could be assumed to be independent, so that OLS regression was used. Backward elimination, with a criterion of $P>0.10$ for removal, was used to arrive at a reduced model for each dependent variable.

Descriptive statistics were estimated from untransformed data, and Spearman's correlation coefficients were determined on data aggregated for each subject.

A $P$-value less than 0.05 was taken to be significant.

\section{Results and discussion}

All environmental and biological sampling has been completed for the whole cohort for the first three 6monthly intervals, i.e., an 18-month period. In this paper, we present results only for $\mathrm{Mn}$ and $\mathrm{Pb}$.

The MMT and Mn results for the major brands of gasoline using MMT ranged from 50 to $90 \mathrm{mg} \mathrm{MMT/L}$ and from 13 to $23 \mathrm{mg} \mathrm{Mn} / \mathrm{L}$, respectively; the recommended "treat rate" is $18 \mathrm{mg} \mathrm{Mn} / \mathrm{L}$ (NICNAS, 2003). The Mn concentrations decreased from $23 \mathrm{mg} / \mathrm{L}$ in 2002 to about $13 \mathrm{mg} / \mathrm{L}$ in 2003 and 2004. MMT is not used in unleaded gasoline, the most widely used product.

For the purposes of the analysis, the time variable was expressed as fractional months, with the first observation for each subject having a value of zero. The average time between observations was then approximately 5.6 months. Where necessary, a $\log _{10}$ transformation of the metal concentrations was used for the analyses to provide approximately normal distributions. Invalid observations and extreme outliers (greater than five standard deviations from the mean) were removed before statistical analysis. Less than $10 \%$ of the samples yielded Mn concentrations less than the limit of detection and were termed nondetects. Various approaches were considered for dealing with nondetects, leading to a decision to assign a value of half the detection limit for the purposes of statistical analysis (Hinwood et al., 2004).

\subsection{Dust fall accumulation (loading) from petri dishes}

Trace metals in house dust can potentially affect the body burden of that metal in children. For example, in the case of $\mathrm{Pb}$, it is generally accepted that a quantitative relationship between household dust levels and blood lead concentrations exists in children (US EPA, 1986; Lanphear et al., 1998). Furthermore, several studies have demonstrated that the amount of dust ingested by the hand-to-mouth route can add significant quantities of trace metals compared with dietary intake (Duggan, 1983; Thornton et al., 1990; Barnes, 1990). It is also accepted that the dust metal loading may provide a better estimate of potential exposure than the metal concentration of the quantity of metal available to a child for ingestion (Charney et al., 1980; Davies et al., 1990; Lanphear et al., 1996, 1998).

Descriptive statistics for $\mathrm{Pb}$ and $\mathrm{Mn}$ are listed in Table 1 and illustrated for $\mathrm{Mn}$ and $\mathrm{Pb}$ in Fig. 1. The petri dish results have not been adjusted for height of the dish above floor level. Although there is quite a lot of information on concentrations of metals in house dust (e.g., Thornton et al., 1990; Fergusson and Kim, 1991; Kim and Fergusson, 1993), almost no data on metal accumulation over time in urban environments exist to allow for comparison, apart from the limited data

Table 1

Descriptive statistics for $\mathrm{Pb}$ and $\mathrm{Mn}$ (untransformed) for dustfall accumulation using petri dishes

\begin{tabular}{lcc}
\hline Petri dish type & $\mathrm{Pb}$ & $\mathrm{Mn}$ \\
\hline Home $(n=201)$ & & \\
Mean & 81.4 & 22.9 \\
Std. dev. & 211.1 & 24.6 \\
Median & 28.1 & 16.2 \\
Min. & 0.4 & 0.2 \\
Max. & 2081 & 196 \\
Geometric mean & 31.0 & 16.0 \\
& & \\
Child Care Center $(n=65)$ & & \\
Mean & 38.9 & 30.0 \\
Std. dev. & 39.6 & 29.8 \\
Median & 28.3 & 22.3 \\
Min. & 0.4 & 0.2 \\
Max. & 234 & 16.6 \\
Geometric mean & 22.5 & \\
\hline
\end{tabular}

Two outliers for $\mathrm{Pb}$ and two for $\mathrm{Mn}$ are omitted. 

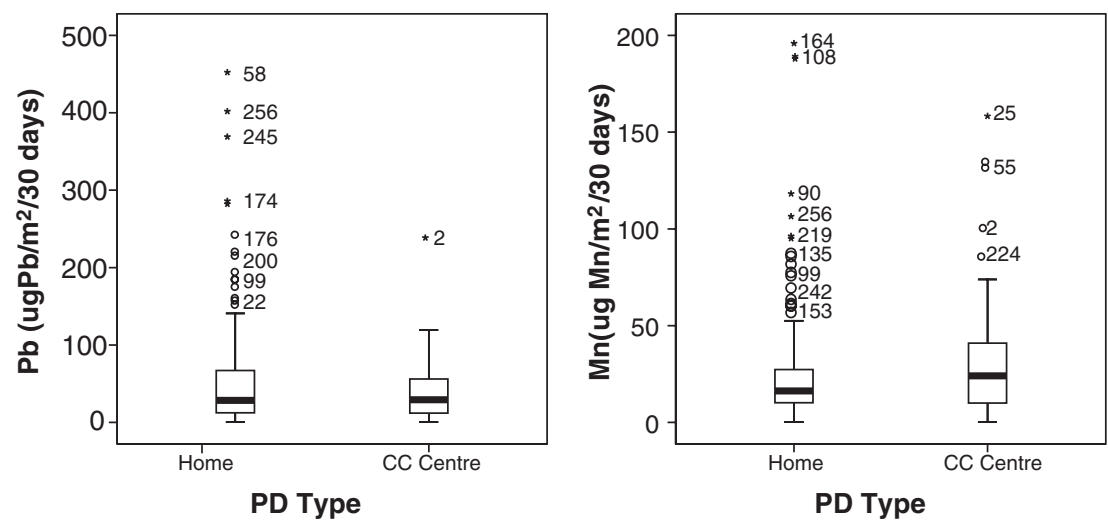

Fig. 1. Box plots for $\mathrm{Pb}$ and $\mathrm{Mn}$ (untransformed) in dustfall accumulation from homes and child care centers. Five values $>500 \mu \mathrm{g} / \mathrm{m}^{2} / 30 \mathrm{days}$ for $\mathrm{Pb}$ from homes and one from a child care center and two values $>500 \mu \mathrm{g} / \mathrm{m}^{2} / 30$ days for $\mathrm{Mn}$ from child care centers were omitted for clarity.

Table 2

Results for $\mathrm{Mn}$ and $\mathrm{Pb}$ from mixed model analyses for dustfall accumulation from the home or child care center

\begin{tabular}{|c|c|c|c|c|c|c|}
\hline Parameter & Estimate & Std. error & $d f$ & $t$ & Sig. & Intraclass correlation \\
\hline \multicolumn{7}{|l|}{$\mathrm{Pb}$} \\
\hline Intercept & 1.375 & 0.088 & 211 & 15.616 & 0.000 & 0.246 \\
\hline Location $^{\mathrm{a}}$ & 0.086 & 0.078 & 230 & 1.113 & 0.267 & \\
\hline Gender $^{\mathrm{a}}$ & 0.105 & 0.087 & 90 & 1.207 & 0.231 & \\
\hline Time & -0.003 & 0.006 & 223 & -0.413 & 0.680 & \\
\hline Traffic exposure & 0.070 & 0.032 & 222 & 2.224 & 0.027 & \\
\hline Age & 0.034 & 0.081 & 92 & 0.425 & 0.672 & \\
\hline \multicolumn{7}{|l|}{$\mathrm{Mn}$} \\
\hline Intercept & 1.243 & 0.071 & 217 & 17.436 & 0.000 & 0.187 \\
\hline Location $^{\mathrm{a}}$ & -0.065 & 0.065 & 240 & -1.004 & 0.317 & \\
\hline Gender $^{\mathrm{a}}$ & -0.006 & 0.068 & 95 & -0.089 & 0.930 & \\
\hline Time & 0.008 & 0.005 & 233 & 1.533 & 0.127 & \\
\hline Traffic exposure & 0.016 & 0.026 & 215 & 0.637 & 0.525 & \\
\hline Age & -0.033 & 0.063 & 98 & -0.522 & 0.603 & \\
\hline
\end{tabular}

Time was measured in months from the first collection. Traffic exposure and age at first collection were centered.

${ }^{\mathrm{a}}$ Location and gender were dummy-coded, with childcare center (for location) and male (for gender) as the reference categories.

available for $\mathrm{Pb}$. For example, over a 10 -year period, the $\mathrm{Pb}$ accumulation in residences in randomly selected areas of Sydney showed a mean of 79 (median 57) and range of 6 to $582 \mu \mathrm{g} \mathrm{Pb} / \mathrm{m}^{2} / 30$ days $(n=302)$ (Gulson et al., 1999). In Germany, dust fall accumulation measured over 1 year is the standard method for measuring dust in houses. Compared to Sydney, 180 house dust samples in Germany had lower mean values and showed much less variation, with $11.4 \mu \mathrm{g} \mathrm{Pb} / \mathrm{m}^{2} / 30$ days (CI 10.5-12.3) (Meyer et al., 1999).

For the mixed-model analyses of dustfall accumulation, neither $\mathrm{Pb}$ nor $\mathrm{Mn}$ values were significantly different for residences compared with daycare centers (Fig. 1). Likewise, there was no significant change over time for $\mathrm{Mn}$ and $\mathrm{Pb}$ or for age. There was a positive relationship between traffic exposure and $\mathrm{Pb}$ but not for Mn. The intraclass correlation (ICC) (Table 2) reflecting the individual variation to total variation was calculated for the final reduced model for each metal; i.e., the analyses were adjusted for the other variables. Values were 0.19 for $\mathrm{Mn}$ and 0.25 for $\mathrm{Pb}$, indicating some dependency between observations for the same individual (i.e., respectively, $19 \%$ and $25 \%$ of the total variation were due to variation between subjects as opposed to variation within subjects).

For the multiple linear regression analyses with dustfall accumulation as the dependent variable and soil and dust sweepings as independent variables, $\mathrm{Pb}$ concentration in soil was the only significant predictor for $\mathrm{Pb}$ in dustfall accumulation, but there were no significant contributions for $\mathrm{Mn}$ from soil or dust sweepings (Table 3 ).

Spearman's correlation coefficients show significant positive correlations for $\mathrm{Mn}$ and $\mathrm{Pb}$ at the 0.01 significance level in the dust from homes and day care centers. However, there are several limitations for the 
dust loading results. The amount of metals deposited in residences depends on location with respect to major traffic thoroughfares, traffic density, meteorology, topography, housing type especially roofing, and the amount of time that windows and doors are open. At this stage, no attempt has been made to control for these variables apart from "traffic exposure" and, in this case, there was

Table 3

Results for multiple regression analyses with $\mathrm{Mn}$ and $\mathrm{Pb}$ in dustfall accumulation as dependent variables

\begin{tabular}{|c|c|c|c|c|c|}
\hline \multirow[t]{2}{*}{ Metal } & \multirow[t]{2}{*}{ Model } & \multicolumn{2}{|c|}{ Unstandardized coefficients } & \multirow[t]{2}{*}{$t$} & \multirow[t]{2}{*}{ Sig. } \\
\hline & & $B$ & Std. error & & \\
\hline \multirow[t]{3}{*}{$\mathrm{Pb}$} & (Constant) & 0.424 & 0.187 & 2.267 & 0.026 \\
\hline & $\mathrm{s} \_\mathrm{Pb}$ & 0.360 & 0.107 & 3.383 & 0.001 \\
\hline & $\overline{\mathrm{ds}} \_\mathrm{Pb}$ & 0.135 & 0.099 & 1.359 & 0.178 \\
\hline \multirow[t]{3}{*}{$\mathrm{Mn}$} & (Constant) & 1.101 & 0.321 & 3.428 & 0.001 \\
\hline & s_Mn & -0.023 & 0.147 & -0.158 & 0.874 \\
\hline & $\overline{\mathrm{ds}} \mathrm{Mn}$ & 0.073 & 0.112 & 0.648 & 0.519 \\
\hline
\end{tabular}

s, soil; ds, dust sweepings. a significant association only between $\mathrm{Pb}$ in the dust and traffic exposure (Table 3).

\subsection{Handwipes}

As hand-to-mouth activity is the principal route contributing to metal exposure of young children, an estimate of metal exposure can be gained from handwipes. The descriptive statistics for handwipes collected prior to and after playing outdoors are listed in Table 4.

The concentration of $\mathrm{Pb}$ in wipes 2, taken after playing outdoors, was significantly greater than that for wipes 1 (Tables 4 and 5). There were no significant effects associated with traffic exposure, although the relationship was positive and $P<0.10$ for $\mathrm{Pb}$. The concentrations of both metals tended to be higher for boys than girls, $P<0.10$ in each case. A follow-up analysis showed that for $\mathrm{Pb}$ there was a significant gender-by-wipe-type interaction, which suggested that the difference between boys and girls was different

Table 4

Descriptive statistics for hand wipes (values in $\mu \mathrm{g} / \mathrm{hand}$; untransformed data)

\begin{tabular}{|c|c|c|c|c|c|c|c|c|}
\hline Wipe type & Sex & Mean & Std. dev. & Median & Min & $\operatorname{Max}$ & Geometric mean & $N$ \\
\hline \multicolumn{9}{|l|}{$\mathrm{Pb}$} \\
\hline \multirow[t]{2}{*}{ Before play } & Female & 3.4 & 4.0 & 1.95 & 0.2 & 28.0 & 2.3 & 128 \\
\hline & Male & 3.6 & 6.2 & 2.30 & 0.1 & 71.0 & 2.4 & 157 \\
\hline \multirow[t]{2}{*}{ After play } & Female & 6.0 & 8.4 & 2.90 & 0.3 & 45.0 & 3.3 & 76 \\
\hline & Male & 14.2 & 43.4 & 4.95 & 0.4 & 330.0 & 5.3 & 92 \\
\hline \multicolumn{9}{|l|}{$\mathrm{Mn}$} \\
\hline \multirow[t]{2}{*}{ Before play } & Female & 6.3 & 8.3 & 1.2 & 0.1 & 24.0 & 2.2 & 128 \\
\hline & Male & 6.9 & 8.4 & 1.6 & 0.0 & 25.0 & 2.6 & 157 \\
\hline \multirow[t]{2}{*}{ After play } & Female & 4.7 & 6.1 & 1.6 & 0.1 & 27.0 & 2.2 & 76 \\
\hline & Male & 5.9 & 7.7 & 2.6 & 0.2 & 53.0 & 3.1 & 92 \\
\hline
\end{tabular}

Table 5

Results for $\mathrm{Pb}$ and $\mathrm{Mn}$ from mixed model analyses for handwipes

\begin{tabular}{|c|c|c|c|c|c|c|}
\hline Parameter & Estimate & Std. error & $d f$ & $t$ & Sig. & Intraclass correlation \\
\hline \multicolumn{7}{|l|}{$\mathrm{Pb}$} \\
\hline Intercept & 0.740 & 0.050 & 297 & 14.696 & 0.000 & 0.237 \\
\hline Wipe type $^{\mathrm{a}}$ & -0.294 & 0.036 & 380 & -8.152 & 0.000 & \\
\hline Gender $^{\mathrm{a}}$ & -0.090 & 0.051 & 116 & -1.765 & 0.080 & \\
\hline Time & -0.007 & 0.004 & 416 & -2.028 & 0.043 & \\
\hline Traffic exposure & 0.037 & 0.019 & 135 & 1.940 & 0.054 & \\
\hline Age & 0.164 & 0.048 & 97 & 3.386 & 0.001 & \\
\hline \multicolumn{7}{|l|}{$\mathrm{Mn}$} \\
\hline Intercept & 0.703 & 0.073 & 314 & 9.690 & 0.000 & 0.119 \\
\hline Wipe type $^{\mathrm{a}}$ & -0.123 & 0.057 & 385 & -2.165 & 0.031 & \\
\hline Gender $^{\mathrm{a}}$ & -0.132 & 0.067 & 100 & -1.961 & 0.053 & \\
\hline Time & -0.026 & 0.006 & 429 & -4.650 & 0.000 & \\
\hline Traffic exposure & -0.008 & 0.026 & 108 & -0.304 & 0.762 & \\
\hline Age & 0.006 & 0.063 & 85 & 0.097 & 0.923 & \\
\hline
\end{tabular}

Time was measured in months from the first collection. Traffic exposure and age at first collection were centered at their means.

${ }^{\mathrm{a}}$ Wipe type and gender were dummy-coded, with after (for wipe type) and male (for gender) as the reference categories. 

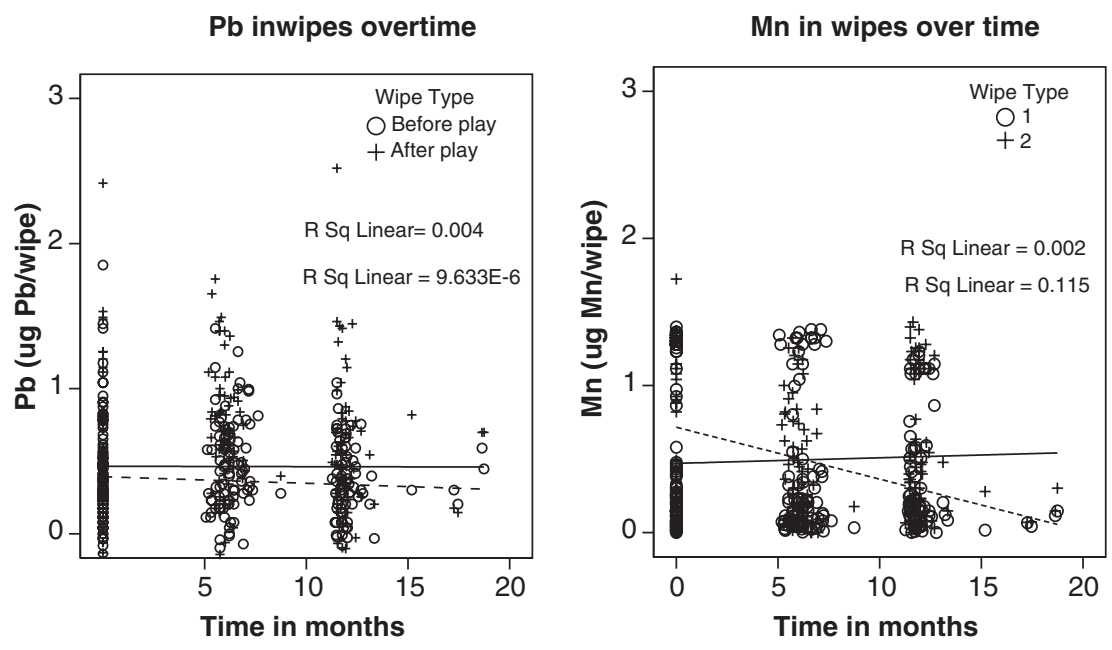

Fig. 2. Scatter plot showing the changes in log lead and manganese in wipes prior to playing (Type 1) and after playing outdoors (Type 2). Dashed lines are type 1 . There is a significant decrease in manganese over time for wipe type 1 .

before and after play. Tests of simple effects showed that the difference before play was not significant $(P=0.578)$ but that the difference after play was $(P=0.005)$. There was a significant effect of age for $\mathrm{Pb}$ level, with older subjects having higher $\mathrm{Pb}$ levels. There were significant decreases in $\mathrm{Pb}$ and $\mathrm{Mn}$ concentrations over time (Fig. 2), especially for the wipes taken prior to playing. A follow-up analysis showed that, for $\mathrm{Mn}$, there was a significant time-bywipe-type interaction $(P=0.003)$. Tests of simple slopes showed that there was a significant decrease in Mn over time for wipes taken before play $(P<0.0005)$ but none for wipes taken after play $(P=0.722)$. At this stage, no explanation can be offered for the decrease in Mn before play. In the mixed-model analyses the intraclass correlations were 0.12 for $\mathrm{Mn}$ and 0.24 for $\mathrm{Pb}$, indicating some dependency between observations from the same individual (Table 5) with approximately $20 \%$ of the variance for $\mathrm{Pb}$ and $10 \%$ for $\mathrm{Mn}$ due to differences between subjects.

For the multiple linear regression analyses, dustfall accumulation was a significant predictor for $\mathrm{Pb}$ in wipes prior to playing outside whereas dust sweepings were a significant predictor of Mn (Table 6). For the wipes taken after playing outdoors, dust sweepings were a significant predictor for $\mathrm{Pb}$ but surprisingly, not in the case of Mn.

There are significant positive correlation coefficients at the 0.01 level in $\mathrm{Mn}$ and $\mathrm{Pb}$ for wipes both taken prior to and after the child had been playing outdoors.

Despite their potential usefulness, there are limited data for handwipes in children. For example, for 21 children aged 9-24 months living in Omaha, Nebraska, the geometric mean of lead in handwipes was $0.89 \mu \mathrm{g} \mathrm{Pb}$ (range 0.46-2.3) (Manton et al., 2000), lower than the values found in our study for a similar age group. In contrast, Viverette et al. (1996) measured highly varying
Table 6

Results for $\mathrm{Pb}$ and $\mathrm{Mn}$ of multiple regression analyses for handwipes

\begin{tabular}{|c|c|c|c|c|c|}
\hline \multirow[t]{2}{*}{ Metal } & \multirow[t]{2}{*}{ Model } & \multicolumn{2}{|c|}{ Unstandardized coefficients } & \multirow[t]{2}{*}{$t$} & \multirow[t]{2}{*}{ Sig. } \\
\hline & & B & Std. error & & \\
\hline \multicolumn{6}{|c|}{ Wipes prior to playing } \\
\hline \multirow[t]{4}{*}{$\mathrm{Pb}$} & (Constant) & 0.076 & 0.102 & 0.743 & 0.460 \\
\hline & pd_Pb & 0.140 & 0.056 & 2.508 & 0.014 \\
\hline & s_ $\overline{\mathrm{Pb}}$ & 0.022 & 0.060 & 0.361 & 0.719 \\
\hline & $\overline{\mathrm{ds}} \_\mathrm{Pb}$ & 0.014 & 0.053 & 0.263 & 0.794 \\
\hline \multirow[t]{4}{*}{$\mathrm{Mn}$} & (Constant) & 0.720 & 0.388 & 1.856 & 0.067 \\
\hline & pd_Mn & -0.042 & 0.119 & -0.351 & 0.726 \\
\hline & s_- $\mathrm{Mn}$ & 0.199 & 0.167 & 1.197 & 0.235 \\
\hline & ds_Mn & -0.358 & 0.128 & -2.806 & 0.006 \\
\hline \multicolumn{6}{|c|}{ Wipes after playing } \\
\hline \multirow[t]{4}{*}{$\mathrm{Pb}$} & (Constant) & -0.069 & 0.171 & -0.401 & 0.690 \\
\hline & pd_Pb & -0.059 & 0.089 & -0.666 & 0.507 \\
\hline & s_t $\overline{\mathrm{Pb}}$ & 0.076 & 0.102 & 0.749 & 0.456 \\
\hline & $\overline{\mathrm{ds}} \_\mathrm{Pb}$ & 0.286 & 0.096 & 2.977 & 0.004 \\
\hline \multirow[t]{4}{*}{$\mathrm{Mn}$} & (Constant) & 0.093 & 0.397 & 0.235 & 0.815 \\
\hline & pd_Mn & 0.140 & 0.124 & 1.135 & 0.260 \\
\hline & s_- $\bar{M} n$ & -0.114 & 0.172 & -0.664 & 0.508 \\
\hline & ds_Mn & 0.216 & 0.146 & 1.485 & 0.141 \\
\hline
\end{tabular}

pd, dustfall accumulation using petri dishes; s, soil; ds, dust sweepings.

amounts of lead on handwipes from African-American children aged 3-6 years attending four daycare centers in New Orleans, LA. The average for 10 children from each center was $2.8 \mu \mathrm{g} \mathrm{Pb} /$ hand for boys and $1.9 \mu \mathrm{g} \mathrm{Pb} /$ hand for girls before playing outdoors. After playing outside, the averages were 10.2 and $6.7 \mu \mathrm{g} / \mathrm{hand}$, respectively, representing a greater than $30 \%$ increase after playing. For the case of a private inner city center, the average increase was $\ll 100 \%$. In a comprehensive investigation of children aged 10-12 years living in rural, urban, and nonferrous smelter areas in Belgium, Buchet 
Table 7

Descriptive statistics for duplicate diets (untransformed data)

\begin{tabular}{|c|c|c|c|c|c|c|}
\hline & $\mathrm{Pb}(\mu \mathrm{g} / \mathrm{kg})$ & $\mathrm{Mn}(\mathrm{mg} / \mathrm{kg})$ & Mn DI (mg) & Mn DI bw $(\mathrm{mg} / \mathrm{kg})$ & $\mathrm{Pb}$ DI $(\mu \mathrm{g})$ & $\mathrm{Pb}$ DI bw $(\mu \mathrm{g} / \mathrm{kg})$ \\
\hline Mean & 9.28 & 2.73 & 2.27 & 0.18 & 8.13 & 0.64 \\
\hline Std. deviation & 8.18 & 1.28 & 1.45 & 0.13 & 8.45 & 0.71 \\
\hline Median & 7.20 & 2.60 & 2.01 & 0.15 & 6.41 & 0.49 \\
\hline Geometric mean & 7.26 & 2.44 & 1.88 & & 6.03 & \\
\hline Minimum & 2.50 & 0.23 & 0.06 & 0.00 & 1.07 & 0.00 \\
\hline Maximum & 82.00 & 8.20 & 12.12 & 1.10 & 65.12 & 6.51 \\
\hline$N$ & 397 & 397 & 391 & 391 & 391 & 391 \\
\hline
\end{tabular}

Table 8

Results of mixed model analyses in duplicate diets

\begin{tabular}{|c|c|c|c|c|c|c|}
\hline Parameter & Estimate & Std. error & $d f$ & $t$ & Sig. & Intraclass correlation \\
\hline \multicolumn{7}{|l|}{ Mn DI (log mg) } \\
\hline Intercept & 0.204 & 0.054 & 138 & 3.780 & 0.000 & 0.241 \\
\hline Time & 0.016 & 0.003 & 220 & 5.652 & 0.000 & \\
\hline Traffic exposure & -0.007 & 0.013 & 126 & -0.490 & 0.625 & \\
\hline \multicolumn{7}{|l|}{$\mathrm{Mn} \mathrm{DI} / \mathrm{bw}$} \\
\hline Intercept & -0.847 & 0.053 & 131 & -15.899 & 0.000 & 0.203 \\
\hline Time & 0.007 & 0.003 & 217 & 2.600 & 0.010 & \\
\hline Traffic exposure & 0.003 & 0.013 & 120 & 0.213 & 0.832 & \\
\hline \multicolumn{7}{|l|}{$\mathrm{Pb} \mathrm{DI}(\log \mu \mathrm{g})$} \\
\hline Intercept & 0.841 & 0.073 & 270 & 11.574 & 0.000 & 0.186 \\
\hline Time & 0.023 & 0.015 & 247 & 1.557 & 0.121 & \\
\hline Traffic exposure & -0.050 & 0.018 & 269 & -2.736 & 0.007 & \\
\hline Time*Traffic exposure & 0.005 & 0.003 & 264 & 2.073 & 0.039 & \\
\hline \multicolumn{7}{|l|}{$\mathrm{Pb} \mathrm{DI} / \mathrm{bw}$} \\
\hline Intercept & -0.203 & 0.078 & 243 & -2.598 & 0.010 & 0.258 \\
\hline Time & 0.018 & 0.015 & 227 & 1.208 & 0.228 & \\
\hline Traffic exposure & -0.045 & 0.020 & 244 & -2.318 & 0.021 & \\
\hline Time quadratic & -0.002 & 0.001 & 217 & -2.147 & 0.033 & \\
\hline Time*Traffic exposure & 0.005 & 0.003 & 239 & 2.149 & 0.033 & \\
\hline
\end{tabular}

DI, daily intake; bw, body weight.

et al. (1980) measured As, Cd, and Mn in hand dust by rinsing hands in dilute nitric acid. They found that hand contamination by $\mathrm{Mn}$ was independent of that of other metals and dwelling place. Boys' hands contained more $\mathrm{Mn}$ than those of girls with mean values for boys ranging from about 2 to $3 \mu \mathrm{g} \mathrm{Mn} / \mathrm{hand}$ and for girls it was about 0.5 to $1.5 \mu \mathrm{g} \mathrm{Mn} /$ hand.

\subsection{Diet}

Descriptive statistics for $\mathrm{Pb}$ and $\mathrm{Mn}$ in diet are listed in Table 7. The geometric mean daily intake of $\mathrm{Pb}$ of $6 \mu \mathrm{g} /$ day is the same as the default values of about $6 \mu \mathrm{g}$ $\mathrm{Pb} /$ day used in the US IEUBK model for children of this age. The daily intake of $1.9 \mathrm{mg} \mathrm{Mn}$ /day is considerably higher than the estimated safe and adequate dose of $0.3-1.0 \mathrm{mg} /$ day for infants (Pennington et al., 1986).
Table 9

Descriptive statistics for $\mathrm{Pb}$ and $\mathrm{Mn}$ in blood

\begin{tabular}{lccccc}
\hline & \multicolumn{3}{c}{ Female } & \multicolumn{3}{l}{ Male } \\
\cline { 2 - 3 } \cline { 5 - 6 } & $\operatorname{PbB}(\mu \mathrm{g} / \mathrm{dL})$ & $\mathrm{MnB}(\mu \mathrm{g} / \mathrm{L})$ & $\mathrm{PbB}(\mu \mathrm{g} / \mathrm{dL})$ & $\mathrm{MnB}(\mu \mathrm{g} / \mathrm{L})$ \\
\hline Mean & 3.1 & 12.3 & 3.1 & 12.2 \\
Median & 2.6 & 11.0 & & 2.5 & 11.0 \\
Std. dev. & 2.4 & 4.8 & & 2.5 & 6.0 \\
Min. & 0.6 & 4.1 & & 0.7 & 1.8 \\
Max. & 15.0 & 31.0 & & 19.0 & 45.0 \\
Geometric mean & 2.6 & 11.5 & & 2.6 & 11.0 \\
$N$ & 123 & 117 & 145 & 137 \\
\hline
\end{tabular}

There were significant positive increases over time in the daily intakes and daily intakes/body weight for log $\mathrm{Mn}$ but not for $\log \mathrm{Pb}$ (Table 8 ). There were significant decreases in the daily intakes and daily intakes/body weight for $\log \mathrm{Pb}$ and traffic exposure. A significant 
B. Gulson et al. / Environmental Research 100 (2006) 100-114

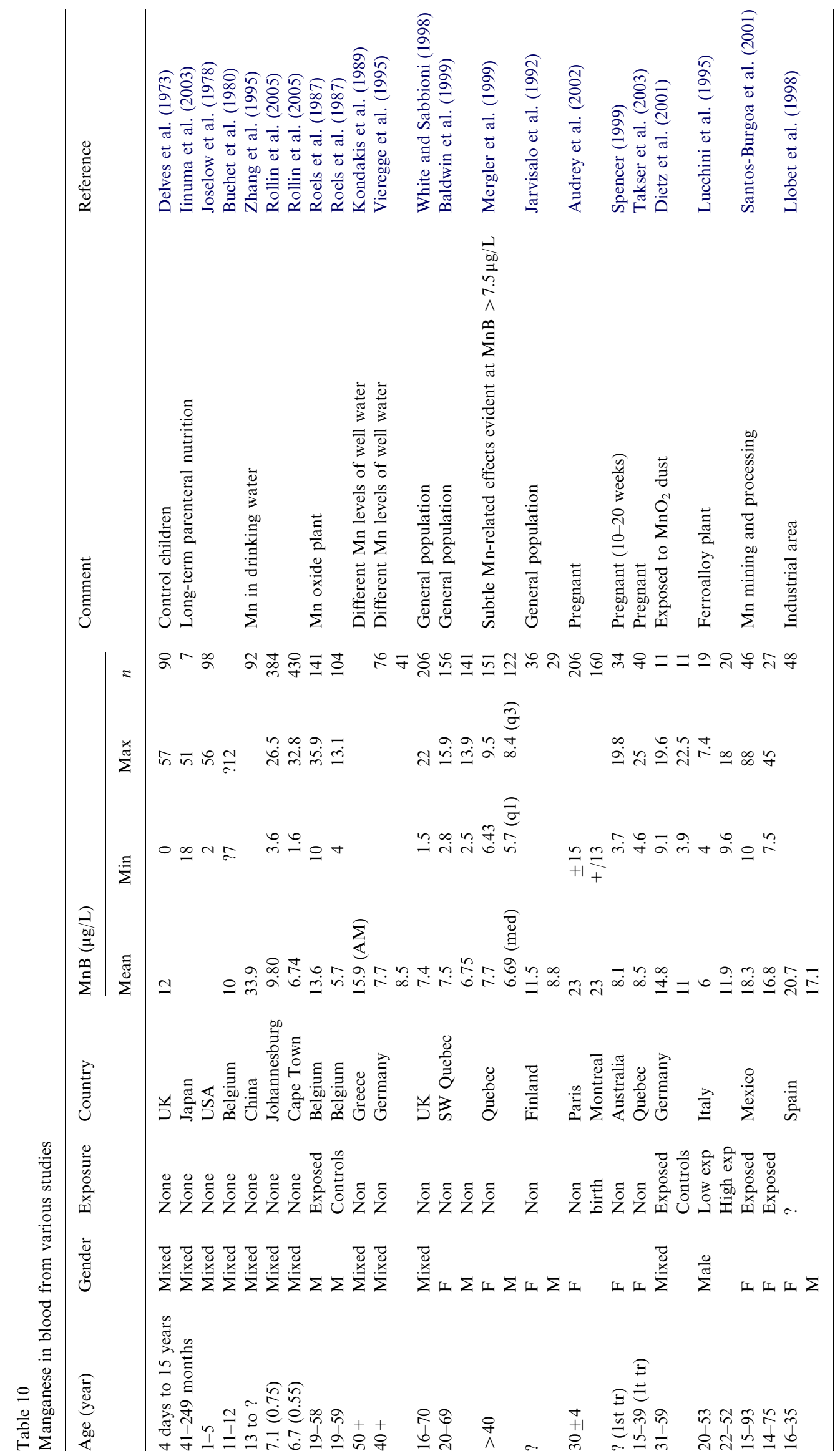


Table 11

Results for $\mathrm{Pb}$ and $\mathrm{Mn}$ from mixed-model analyses for blood

\begin{tabular}{|c|c|c|c|c|c|c|}
\hline Parameter & Estimate & Std. error & $d f$ & $t$ & Sig. & Intraclass correlation \\
\hline \multicolumn{7}{|l|}{$\mathrm{Pb}$} \\
\hline Intercept & 0.446 & 0.030 & 128 & 15.083 & 0.000 & 0.648 \\
\hline Gender $^{\mathrm{a}}$ & -0.008 & 0.040 & 121 & -0.190 & 0.849 & \\
\hline Time & -0.005 & 0.002 & 176 & -3.235 & 0.001 & \\
\hline Traffic exposure & 0.016 & 0.014 & 185 & 1.149 & 0.252 & \\
\hline Age & 0.042 & 0.036 & 148 & 1.170 & 0.244 & \\
\hline \multicolumn{7}{|l|}{$\mathrm{Mn}$} \\
\hline Intercept & 1.051 & 0.023 & 149 & 46.714 & 0.000 & 0.129 \\
\hline Gender $^{\mathrm{a}}$ & 0.015 & 0.029 & 107 & 0.507 & 0.613 & \\
\hline Time & -0.002 & 0.002 & 191 & -1.162 & 0.247 & \\
\hline Traffic exposure & 0.009 & 0.011 & 125 & 0.789 & 0.432 & \\
\hline Age & -0.011 & 0.027 & 120 & -0.410 & 0.683 & \\
\hline
\end{tabular}

Time was measured in months from the first collection. Traffic exposure and age at first collection were centered at their means.

${ }^{\mathrm{a}}$ Gender was dummy-coded, with male as the reference categories.

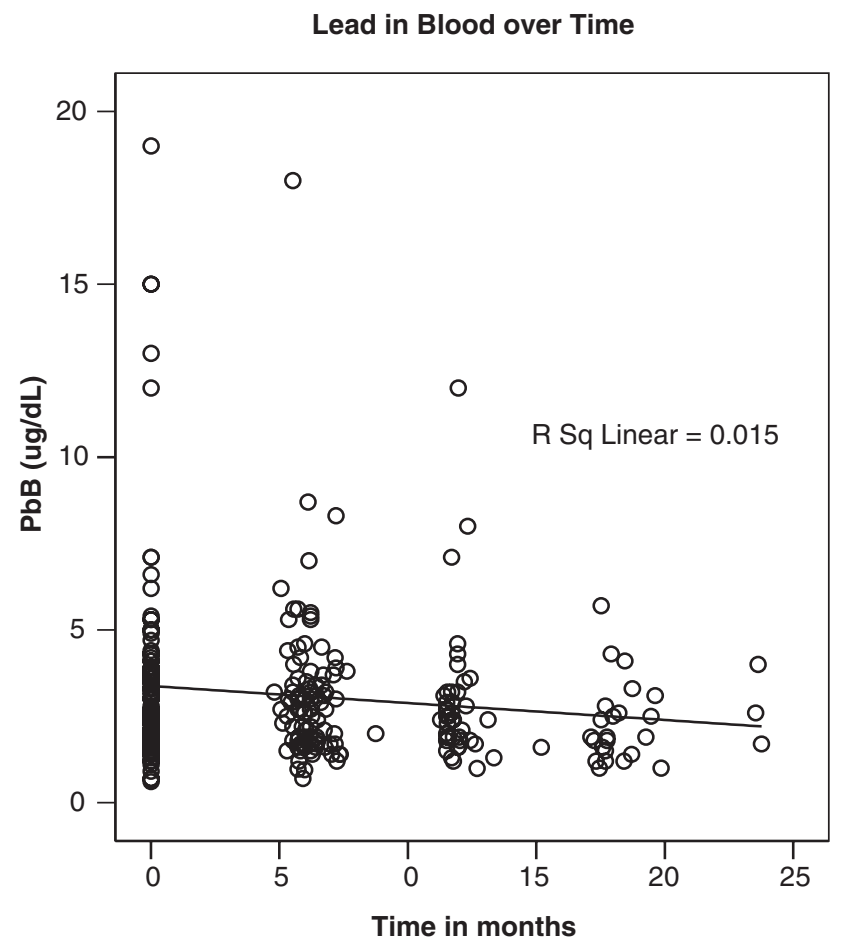

Fig. 3. Decrease in $\mathrm{PbB}$ over time.

positive interaction between traffic exposure and time was observed only for $\mathrm{Pb}$. The variation in daily intake and daily intake/body weight for $\mathrm{Pb}$ and $\mathrm{Mn}$ in diet was greater between individuals than within individuals.

\subsection{Blood}

Results for blood lead and manganese for children are given in Table 9. The lower number of analyses compared with the expected number of about 170 for three sampling periods arises from the inability to obtain blood samples every time or insufficient samples for analysis. As also shown by the mixed-model analysis, there was no difference in the mean $\mathrm{PbB}$ or $\mathrm{MnB}$ for the females and males. Six of the 114 children $(5 \%)$ had a $\mathrm{PbB}>10 \mu \mathrm{g} / \mathrm{dL}$, the current Australian National Health and Medical Research Council guideline. Three of these children had a $\mathrm{PbB}>15 \mu \mathrm{g} / \mathrm{dL}$, requiring notification to the NSW Health department. The elevated PbBs arose from renovations involving $\mathrm{Pb}$ paint and ceiling (attic) dust and, with assistance from the cohort coordinator (K.J.M.), these values are all now below $10 \mu \mathrm{g} / \mathrm{dL}$.

There are very few published data for $\mathrm{Mn}$ in blood of healthy young children, whereas most of the emphasis has focused on children undergoing parenteral nutrition (e.g., Hambidge et al., 1989; Reynolds et al., 1994; Kafritsa et al., 1998; Quaghebeur et al., 1996; Iinuma et al., 2003). Manganese concentrations in blood from some of these studies are listed in Table 10. There are comprehensive data on $\mathrm{Mn}$ and $\mathrm{Pb}$ in blood for schoolaged children from Belgium (Table 10; Buchet et al., 1980). In a study of trace metals in the blood of 90 children admitted to hospital with a variety of disorders, Delves et al. (1973) found a wide range in Mn from 0 to $57 \mu \mathrm{g} / \mathrm{L}$ (mean 12) but there was no correlation with age. Higher concentrations of $\mathrm{Mn}$ in hair and blood $(33.9 \mu \mathrm{g} /$ L) of 92 primary school pupils and lower levels of neurotransmitters compared with control children was attributed to $\mathrm{Mn}$ in drinking water from the Shanxi Province in China (Zhang et al., 1995), although Aschner (2000) has questioned the validity of this study.

Results of a study from South Africa, where MMT was also recently introduced, have recently been published (Rollin et al., 2005). Enlisting a large cohort of school-aged children from Johannesburg $(n=384)$ and Cape Town $(n=430)$, Rollin et al. found significantly higher values of $\mathrm{Mn}$ in blood of the children and in soil and classroom dust for Johannesburg compared 
with Cape Town. Mean values for blood $\mathrm{Mn}$ were $9.80 \mu \mathrm{g} / \mathrm{L}$ in the Johannesburg children compared with $6.74 \mu \mathrm{g} / \mathrm{L}$ for those from Cape Town. Furthermore, they found blood Mn levels of $4.2 \%$ of children in Cape Town and $12.5 \%$ in Johannesburg, equaling or exceeding $14 \mu \mathrm{g} / \mathrm{L}$, the upper normal reference value specified by the Agency for Toxic Substances Disease Registry (ATSDR, 2000). Levels of $\mathrm{Mn}$ in blood were found to be significantly associated with concentrations of $\mathrm{Mn}$ in classroom dust at schools. Although there are significant differences in soil, dust, and blood between Johannesburg and Cape Town, Rollin et al. recognize that these differences may arise from naturally occurring $\mathrm{Mn}$ and not from MMT; Johannesburg is famous for its gold mines and mineralized areas generally have higher concentrations of $\mathrm{Mn}$ compared with unmineralized areas. The blood $\mathrm{Mn}$ values in the South African children are lower than the mean value of $11.6 \mu \mathrm{g} / \mathrm{L}$ that we measured in our cohort and may be partly explained by age differences; homeostatic balance would be well established in the school-aged children. In contrast to the South African children, 27\% of 112 children in our cohort had $\mathrm{MnB}>14 \mu \mathrm{g} / \mathrm{L}$. At this stage it is not possible to advance other explanations of the differences between the countries because market figures for use of MMT are unavailable and there are substantial physiographic, geological, social, and political issues.

There is more information for adults, especially those who were occupationally exposed (e.g., Roels et al., 1987, 1992), and a limited amount for environmentally exposed subjects. Several studies monitored women through pregnancy and cord blood but none of these followed the children into infancy (Hatano et al., 1983, 1985; Tsuchiya et al., 1987; Tholin et al., 1995; Spencer, 1999; Takser et al., 2003). The results for some of these studies are summarized in Table 10. In some cases, the use of Mn-containing fungicides and seed protectants could have explained the higher MnB levels in subjects living in areas where spraying occurred (Takser et al., 2003).

Table 12

Results for $\mathrm{Pb}$ and $\mathrm{Mn}$ of multiple regression analyses for handwipes

\begin{tabular}{|c|c|c|c|c|c|c|c|}
\hline \multirow[t]{2}{*}{ Metal } & \multirow[t]{2}{*}{ Model } & \multirow[t]{2}{*}{$R$} & \multirow[t]{2}{*}{$R^{2}$} & \multicolumn{2}{|c|}{ Unstandardized coefficients } & \multirow[t]{2}{*}{$t$} & \multirow[t]{2}{*}{ Sig. } \\
\hline & & & & $B$ & Std. error & & \\
\hline \multicolumn{8}{|c|}{ Wipes prior to playing } \\
\hline \multirow[t]{8}{*}{$\mathrm{Mn}$} & (Constant) & 0.253 & 0.064 & 0.849 & 0.160 & 5.313 & 0.000 \\
\hline & pd_Mn & & & 0.005 & 0.048 & 0.112 & 0.911 \\
\hline & w_Mn & & & 0.089 & 0.042 & 2.113 & 0.037 \\
\hline & s_- Mn & & & 0.002 & 0.067 & 0.033 & 0.974 \\
\hline & $\overline{\mathrm{ds}} \_\mathrm{Mn}$ & & & 0.056 & 0.053 & 1.051 & 0.296 \\
\hline & MnDImg & & & 0.075 & 0.074 & 1.017 & 0.312 \\
\hline & (Constant) & 0.192 & 0.037 & 1.004 & 0.020 & 49.594 & 0.000 \\
\hline & w_Mn & & & 0.075 & 0.040 & 1.874 & 0.064 \\
\hline \multirow[t]{9}{*}{$\mathrm{Pb}$} & (Constant) & 0.511 & 0.261 & -0.064 & 0.100 & -0.641 & 0.523 \\
\hline & pd_Pb & & & 0.129 & 0.045 & 2.895 & 0.005 \\
\hline & $\mathrm{PbD} \mathrm{I} \mu \mathrm{g}$ & & & 0.151 & 0.090 & 1.678 & 0.097 \\
\hline & w_Pb & & & 0.126 & 0.081 & 1.545 & 0.126 \\
\hline & $\mathrm{s} \_\overline{\mathrm{Pb}}$ & & & 0.026 & 0.047 & 0.553 & 0.582 \\
\hline & $\overline{\mathrm{ds}} \_\mathrm{Pb}$ & & & 0.019 & 0.041 & 0.459 & 0.647 \\
\hline & (Constant) & 0.478 & 0.229 & 0.000 & 0.089 & -0.004 & 0.997 \\
\hline & pd_Pb & & & 0.174 & 0.037 & 4.729 & 0.000 \\
\hline & $\mathrm{PbD} I \mu \mathrm{g}$ & & & 0.167 & 0.090 & 1.860 & 0.066 \\
\hline \multicolumn{8}{|c|}{ Wipes post playing } \\
\hline \multirow[t]{9}{*}{$\mathrm{Pb}$} & (Constant) & 0.557 & 0.310 & -0.122 & 0.107 & -1.141 & 0.257 \\
\hline & S_Pb & & & -0.016 & 0.050 & -0.324 & 0.746 \\
\hline & w_Pb & & & 0.060 & 0.054 & 1.118 & 0.267 \\
\hline & $\mathrm{pd} \_\mathrm{Pb}$ & & & 0.179 & 0.044 & 4.049 & 0.000 \\
\hline & ds_Pb & & & 0.059 & 0.050 & 1.187 & 0.239 \\
\hline & $\mathrm{PbDI} \mu \mathrm{g}$ & & & 0.134 & 0.093 & 1.436 & 0.155 \\
\hline & (Constant) & 0.529 & 0.279 & -0.035 & 0.082 & -0.422 & 0.674 \\
\hline & pd_Pb & & & 0.170 & 0.042 & 4.092 & 0.000 \\
\hline & $\mathrm{ds} \_\mathrm{Pb}$ & & & 0.075 & 0.036 & 2.081 & 0.040 \\
\hline \multicolumn{8}{|c|}{ Mn none significant } \\
\hline
\end{tabular}

s, soil; w, wipes; pd, petri dust; ds, dust sweepings; MnDImg and PbDI $\mu$ g daily intake in $\mathrm{mg}$ or $\mu \mathrm{g}$ of $\mathrm{Mn}$ and $\mathrm{Pb}$, respectively. 
Mixed-model analyses showed that there was a significant decline in $\mathrm{PbB}$ but no significant change in MnB over time (Table 11, Fig. 3). A lack of change over time and age contrasts with a decrease with age in serum Mn for 180 apparently healthy Venezuelan infants (Alarcon et al., 1996). Similarly, the erythrocyte Mn concentration in 165 healthy Japanese children was highest at 1 month (and three to four times that in adults), decreased rapidly, and was constant from 4 months to 11 years of age (Hatano et al., 1983). However, the contrasts in the Venezuelan, Japanese, and our longitudinal studies may arise from the older age of our cohort, the cross-sectional nature of the Venezuelan study, and the differences in sample type (whole blood vs. serum, although this may not be so critical as that for example in the case of $\mathrm{Pb}$, because $\sim 66 \%$ of $\mathrm{Mn}$ resides in the erythrocytes). The intraclass correlation for $\mathrm{PbB}$ of 0.65 indicates that the variation between individuals is significantly greater than that within individuals and contrasts with the smaller coefficients obtained for the other measurements considered here.

The only significant predictor for blood lead was dust fall accumulation although dietary intake may also be important (Table 12). The only significant predictor for blood $\mathrm{Mn}$ was $\mathrm{Mn}$ concentrations in handwipes prior to playing for the full model but this variable was not significant in the final, reduced, model.

\section{Conclusion}

At this stage of our longitudinal study and for this paper, we have focused on results for $\mathrm{Mn}$ and $\mathrm{Pb}$. In addition, we restricted the discussion to the environmental samples of handwipes and house and daycare center dust (dustfall and dust sweepings) as these are the most direct pathway to children. So far we have not found an association between $\mathrm{Mn}$ and $\mathrm{Pb}$ in handwipes from the location of the residences with respect to major thoroughfares (traffic exposure) but there was a positive association of traffic exposure with $\mathrm{Pb}$ in dust. Furthermore, there appear to be significant decreases in both $\mathrm{Pb}$ and $\mathrm{Mn}$ over time for the handwipes although this was not found in the dustfall accumulation. The decrease in $\mathrm{Pb}$ could be expected as $\mathrm{Pb}$ has been removed from gasoline in major Australian cities since 2002, but the decrease in Mn was not expected because of the introduction of MMT. However, as stated earlier, the 2002 levels of $\mathrm{Mn}$ in gasoline ranged from 13.1 to $22.6 \mathrm{mg} \mathrm{Mn} / \mathrm{L}$ and for 2003 and 2004 they were about $13 \mathrm{mg} \mathrm{Mn} / \mathrm{L}$; these changes may explain the decreases in $\mathrm{Mn}$ in the handwipes. Ongoing investigations, especially for air samples, should provide more definitive information on potential changes to the environment and exposure of young children associated with the introduction of MMT and phasing out of $\mathrm{Pb}$ in Australian gasoline.

\section{Acknowledgments}

We thank Laura Munoz for technical assistance, Marilyn Morgan for phlebotomy, the parents for allowing participation of their children, Becton-Dickinson, AstraZeneca, and Johnson \& Johnson for consumables for sampling, and the NSW Roads and Traffic Authority for allowing access to their traffic data.

\section{References}

Alarcon, O.M., Reinosa-Fuller, J.A., Silva, T., Ramirez de Fernandez, M., Gamboa, J., 1996. Manganese levels in serum of healthy Venezuelan infants living in Merida. J. Trace Elem. Med. Biol. 10, 210-213.

Aschner, M., 2000. Manganese: brain transport and emerging research needs. Environ. Health Perspect. 108 (3), 429-432.

ATSDR, 2000. Toxicological Profile for Manganese. Agency for Toxic Substances and Disease Registry, Atlanta, GA.

Audrey, S., Takser, L., Andre, M., Martin, S., Mergler, D., Genevieve, St-A., et al., 2002. A comparative study of manganese and lead levels inhuman umbilical cords and maternal blood from two urban centers exposed to different gasoline additives. Sci. Total Environ. 290, 157-164.

Baldwin, M., Mergler, D., Larribe, F., Belanger, S., Tardif, R., Bilodeau, L., Hudnell, K., 1999. Bioindicator and exposure data for a population based study of manganese. Neurotoxicology 20, 343-354.

Barnes, R.M., 1990. Childhood soil ingestion: how much dirt do kids eat? Anal. Chem. 62, 1023A-1033A.

Bhuie, A.K., Roy, D.N., 2001. Deposition of Mn from automotive combustion of methylcyclopentadienyl manganese tricarbonyl beside the major highways in the greater Toronto area, Canada. J. Air Waste Manage. Assoc. 51, 1288-1301.

Buchet, J.P., Roels, H., Lauwerys, R., Bruaux, P., Claeys-Thoreau, F., Lafontaine, A., Verduyn, G., 1980. Repeated surveillance of exposure to cadmium, manganese, and arsenic in school-age children living in rural, urban, and nonferrous smelter areas in Belgium. Environ. Res. 22, 95-108.

Charney, E., Sayre, J., Coulter, M., 1980. Increased lead absorption in inner city children: where does the lead come from? Pediatrics 65 , 226-231.

Clayton, C.A., Pellizzari, E.D., Rodes, C.E., Mason, R.E., Piper, L.L., 1999. Estimating distributions of long-term particulate matter and manganese exposures for residents of Toronto, Canada. Atmos. Environ. 33, 2515-2526.

Crump, K.S., 2000. Manganese exposures in Toronto during use of the gasoline additive, methylcyclopentadienyl manganese tricarbonyl. J. Expo. Anal. Environ. Epidemiol. 10, 227-239.

Davies, D.J., Thornton, I., Watt, J.M., Culbard, E.B., Harvey, P.G., Delves, H.T., et al., 1990. Lead intake and blood lead in two-yearold UK urban children. Sci. Total Environ. 90, 13-29.

Davis, J.M., 1998. Methylcyclopentadienyl manganese tricarbonyl: health risk uncertainties and research directions. Environ. Health Perspect. 106, 191-201.

Davis, J.M., 2001. Manganese and rhenium. In: Bingham et al. (Ed.), Patty's Toxicology, 5th ed., vol. 3. Wiley, New York, pp. 129-168. 
Davis, J.M., 2004. EPA Alternative Tier 2 Studies for MMT. Presentation at Health Effects Institute Annual Conference, Boston, MA, May 2-4 (available at: http://www.healtheffects.org/Slides/AnnConf2004/Davis.pdf).

Davis, J.M., Grant, L.D., 2003. Experiencias de la instauración de normas relativas al contenido de plomo en aire y el agua, en los Estado Unidos de América [Some lessons from the US regulatory experience with lead in air and water]. Salud Publica de Mexico 45 (Suppl.2), S237-S243.

Davis, J.M., Jarabek, Mage, D.T., Graham, J.A., 1998. The EPA health risk assessment of methylcyclopentadienyl manganese tricarbonyl (MMT). Risk Anal. 18, 57-70.

De Miguel, E., Llamas, J.F., Chacon, E., Berg, T., Larssen, S., Royset, O., et al., 1997. Origin and patterns of distribution of trace elements in street dust: unleaded petrol and urban lead. Atmos. Environ. 31, 2733-2740.

Delves, H.T., Clayton, B.E., Bicknell, J., 1973. Concentration of trace metals in the blood of children. Br. J. Prev. Soc. Med. 27, $100-107$.

Dietz, M.C., Ihrig, A., Wrazidlo, W., Bader, M., Jansen, O., Triebig, G., 2001. Results of magnetic resonance imaging in long-term manganese dioxide-exposed workers. Environ. Res. 85, 37-40.

Duggan, M.J., 1983. Contribution of lead in dust to children's blood lead. Environ. Health Perspect. 50, 371-381.

Ethyl Corporation, 2003. Annual Report and Form 10-K. Ethyl Corp., Richmond, VA (available at: http://www.newmarket.com/NR/ rdonlyres/E9942627-D78D-4B94-90B0-8D56C08F5DF2/0/ EY_2003_AR_10k.pdf).

Fergusson, J.E., Kim, N.D., 1991. Trace elements in street and house dusts: sources and speciation. Sci. Total Environ. 100, 125-150.

Gulson, B.L., Davis, J.J., Mizon, K.J., Korsch, M.J., Bawden-Smith, J., 1995. Sources of lead in soil and dust and the use of dust fallout as a sampling medium. Sci. Total Environ. 166, 245-262.

Gulson, B.L., Mahaffey, K.R., Vidal, M., Jameson, C.W., Law, A.J., Mizon, K.J., et al., 1997. Dietary lead intakes for mother/child pairs and relevance to pharmacokinetic models. Environ. Health Perspect. 105, 1334-1342.

Gulson, B.L., Mahaffey, K.R., Jameson, C.W., Patison, N., Law, A.J., Mizon, K.J., et al., 1999. Impact of diet on lead in blood and urine in female adults and relevance to mobilization of lead from bone stores. Environ. Health Perspect. 107, 257-263.

Hambidge, K.M., Sokol, R.J., Fidanza, S.J., Goodall, M.A., 1989. Plasma manganese concentrations in infants and children receiving parenteral nutrition. J. Parenter. Enteral. Nutr. 13, 168-171.

Hatano, S., Nishi, Y., Usui, T., 1983. Erythrocyte manganese concentration in healthy Japanese children, adults, and the elderly, and in cord blood. Am. J. Clin. Nutr. 37, 457-460.

Health Canada, 2003. Assessment of Toxicological Risks of Environmental Contamination by Manganese. TRSI-109. Toxic Substances Research Initiative, Montreal, Que., Canada.

Hinwood, A.L., Sim, M.R., Jolley, D., de Klerk, N., Bastone, E.B., Gerostamoulos, J., et al., 2004. Exposure to inorganic arsenic in soil increases urinary inorganic arsenic concentrations of residents living in old mining areas. Environ. Geochem. Health 26, 27-36.

Iinuma, Y., Kubota, M., Uchiyama, M., Yagi, M., Kanada, S., Yamazaki, S., et al., 2003. Whole-blood manganese levels and brain manganese accumulation in children receiving long-term home parenteral nutrition. Pediatr. Surg. Int. 19, 268-272.

Jarvisalo, J., Olkinuora, M., Kiilunen, M., Kivisto, H., Ristola, P., Tossavainen, A., et al., 1992. Urinary and blood manganese in occupationally nonexposed populations and in manual metal arc welders of mild steel. Int. Arch. Occup. Environ. Health 63, 495-501.

Joselow, M.M., Tobias, E., Koehler, R., Coleman, S., Bogden, J., Gause, D., 1978. Manganese pollution in the city environment and its relationship to traffic density. Am. J. Public Health 68, 557-560.
Kafritsa, Y., Fell, J., Long, S., Bynevelt, M., Taylor, W., Milla, P., 1998. Long-term outcome of brain manganese deposition in patients on home parenteral nutrition. Arch. Dis. Child 79, 263-265.

Kim, N., Fergusson, J., 1993. Concentrations and sources of cadmium, copper, lead and zinc in house dust in Christchurch, New Zealand. Sci. Total Environ. 138, 1-21.

Kondakis, X.G., Makris, N., Leotsinidis, M., et al., 1989. Possible health effects of high manganese concentration in drinking water. Arch. Environ. Health 44, 175-178.

Lanphear, B.P., Weitzman, M., Winter, N.L., Eberly, S., Yakir, B., Tanner, M., et al., 1996. Lead-contaminated house dust and urban children's blood lead levels. Am. J. Public Health 86, 1416-1421.

Lanphear, B.P., Matte, T.D., Rogers, J., Clickner, R.P., Dietz, B., Bornschein, R.L., et al., 1998. The contribution of lead-contaminated house dust and residential soil to children's blood lead levels. A pooled analysis of 12 epidemiologic studies. Environ. Res. 79, 51-68.

Llobet, J.M., Granero, S., Torres, A., Schuhmacher, M., Domingo, J.L., 1998. Biological monitoring of environmental pollution and human exposure to metals in Tarragona, Spain. III. Blood levels. Trace Elem. Electroly. 15, 76-80.

Lucchini, R., Selis, L., Folli, D., Apostoli, P., Mutti, A., Vanoni, O., et al., 1995. Neurobehavioral effects of manganese in workers from a ferroalloy plant after temporary cessation of exposure. Scand. J. Work Environ Health 21, 143-149.

Manton, W.I., Angle, C.R., Stanek, K.L., Reese, Y.R., Kuehnemann, T.J., 2000. Acquisition and retention of lead by young children. Environ. Res. 82, 60-80.

Mergler, D., Baldwin, M., Bélanger, S., et al., 1999. Manganese neurotoxicity, a continuum of dysfunction: Results from a community based study. Neurotoxicology 20, 327-342.

Meyer, I., Heinrich, J., Lippold, U., 1999. Factors affecting lead, cadmium, and arsenic levels in house dust in a smelter town in eastern Germany. Environ. Res. 81, 32-44.

Mielke, H.W., Gonzales, C.R., Powell, E., Shah, A., Mielke, P.W., 2002. Natural and anthropogenic processes that concentrate $\mathrm{Mn}$ in rural and urban environments of the lower Mississippi River delta. Environ. Res. 90, 157-168.

Monna, F., Lancelot, J., Croudace, I.W., Cundy, A.B., Lewis, J.T., 1997. $\mathrm{Pb}$ isotopic composition of airborne particulate material from France and the southern United Kingdom: implications for $\mathrm{Pb}$ pollution sources in urban areas. Environ. Sci. Technol. 31, 2277-2286.

National Industrial Chemicals Notification and Assessment Scheme (NICNAS), 2003. Methylcyclopentadienyl manganese tricarbonyl (MMT): Priority Existing Chemical Assessment Report No. 24. NICNAS, Sydney, NSW, Australia. (available at: http://www.nicnas.gov.au/publications/CAR/PEC/PEC24/pec24.pdf).

Pellizzari, E.D., Clayton, C.A., Rodes, C.E., Mason, R.E., Piper, L.L., Fort, B., et al., 1999. Particulate matter and manganese exposures in Toronto, Canada. Atmos. Environ. 33, 721-734.

Pellizzari, E.D., Clayton, C.A., Rodes, C.E., Mason, R.E., Piper, L.L., Fort, B., et al., 2001. Particulate matter and manganese exposures in Indianapolis, Indiana. J. Expo. Anal. Environ. Epidemiol. 11, 423-440.

Pennington, J.A.T., Young, B.E., Wilson, D.B., et al., 1986. Mineral content of food and total diets: the selected minerals in food survey. J. Am. Diet Assoc. 86, 876-891.

Quaghebeur, G., Taylor, W.J., Kingsley, D.P., Fell, J.M., Reynolds, A.P., Milla, P.J., 1996. MRI in children receiving total parenteral nutrition. Neuroradiology 38, 680-683.

Reynolds, A.P., Kiely, E., Meadows, N., 1994. Manganese in long term paediatric parenteral nutrition. Arch. Dis. Child 71, 527-528.

Rodamilans, M., Torra, M., To-Figueras, J., Corbella, J., Lopez, B., Sanchez, C., et al., 1996. Effect of the reduction of petrol lead on 
blood lead levels of the population of Barcelona (Spain). Bull. Environ. Contam. Toxicol. 56, 717-721.

Roels, H., Lauwerys, R., Genet, P., Sarhan, M.J., Fays, M., Hanotiau, I., et al., 1987. Relationship between external and internal parameters of exposure to manganese in workers from a manganese oxide and salt producing plant. Am. J. Ind. Med. 11, 297-305.

Roels, H.A., Ghyselen, P., Buchet, J.P., Ceulemans, E., Lauwerys, R.R., 1992. Assessment of the permissible exposure level to manganese in workers exposed to manganese dioxide dust. Br. J. Ind. Med. 49, 25-34.

Rollin, H., Mathee, A., Levin, J., Theodorou, P., Wewers, F., 2005. Blood manganese concentrations among first-grade schoolchildren in two South African cities. Environ. Res. 97, 93-99.

Santos-Burgoa, C., Rios, C., Mercado, L.A., Arechiga-Serrano, R., Cano-Valle, F., Eden-Wynter, R.A., et al., 2001. Exposure to manganese: health effects on the general population, a pilot study in Central Mexico. Environ. Res. 85, 90-104.

Spencer, A., 1999. Whole blood manganese levels in pregnancy and the neonate. Nutrition 15, 731-734.

Swan, H., 1999. Speciation and quantification of organic manganese compounds in gasoline by gas chromatography atomic emission spectroscopy. Bull. Environ. Contam. Toxicol. 63, 491-498.

Takser, L., Mergler, D., Hellier, G., Sahuquillo, J., Huel, G., 2003. Manganese, monoamine metabolite levels at birth, and child psychomotor development. Neurotoxicology 24, 667-674.

Tholin, K., Sandstrom, B., Palm, R., Hallmans, G., 1995. Changes in blood manganese levels during pregnancy in iron supplemented and non-supplemented women. J. Trace Elem. Med. Biol. 9, 13-17.

Thomas, V.M., Socolow, R.H., Fanelli, J.J., Spiro, T.G., 1999. Effects of reducing lead in gasoline: an analysis of the international experience. Environ. Sci. Technol. 33, 3942-3948.

Thornton, I., Davies, D.J., Watt, J.M., Quinn, M.J., 1990. Lead exposure in young children from dust and soil in the United Kingdom. Environ. Health Perspect. 89, 55-60.

Tsuchiya, H., Shima, S., Kurita, H., et al., 1987. Effects of maternal exposure to six heavy metals on fetal development. Bull. Environ. Contam. Toxicol. 38, 580-587.

US Environmental Protection Agency, 1986. Air Quality Criteria for Lead. Environmental Criteria and Assessment Office, US Environmental Protection Agency, Research Triangle Park, NC, EPA-600/ $8-83 / 028 \mathrm{aF}$.

US Environmental Protection Agency, 1990. Air quality criteria for lead: supplement to the 1986 Addendum. Office of Health and Environmental Assessment, Environmental Criteria and Assess- ment Office, US Environmental Protection Agency, Research Triangle Park, NC, EPA-600/8-89/049F.

US Environmental Protection Agency, 1991. Information needed to improve the risk characterization of manganese tetraoxide $\left(\mathrm{Mn}_{3} \mathrm{O}_{4}\right)$ and methylcyclopentadienyl manganese tricarbonyl (MMT). US Environmental Protection Agency, Office of Research and Development, Washington, DC.

US Environmental Protection Agency, 1993. Inhalation reference concentration (RfC) for manganese. US Environmental Protection Agency, Integrated Risk Information System (IRIS) database, Washington, DC (available at: http://www.epa.gov/iris/subst/ 0373.htm).

US Environmental Protection Agency, 1994. Reevaluation of inhalation health risks associated with methylcyclopentadienyl manganese tricarbonyl (MMT) in gasoline. Office of Research and Development, US Environmental Protection Agency, Research Triangle Park, NC, EPA Report No. 600/R-94/062.

Vieregge, P., Heinzow, B., Korf, G., et al., 1995. Long term exposure to manganese in rural well water has no neurological effects. Can. J. Neurol. Sci. 22, 286-289.

Viverette, L., Mielke, H.W., Brisco, M., Dixon, A., Schaefer, J., Pierre, K., 1996. Environmental health in minority and other underserved populations: benign methods for identifying lead hazards at day care centres of New Orleans. Environ. Geochem. Health 18, 41-45.

Von Storch, H., Costa-Cabral, M., Hagner, C., Fesera, F., Pacyna, J., Pacyna, E., et al., 2003. Four decades of gasoline lead emissions and control policies in Europe: a retrospective assessment. Sci. Total Environ. 311, 151-176.

White, M.A., Sabbioni, E., 1998. Trace element reference values in tissues from inhabitants of the European Union. X. A study of 13 elements in blood and urine of a United Kingdom population. Sci. Total Environ. 216, 253-270.

Widory, D., Roy, S., Le Moullec, Y., Goupil, G., Cocherie, A., Guerrot, C., 2004. The origin of atmospheric particles in Paris: a view through carbon and lead isotopes. Atmos. Environ. 38, 953-961.

World Health Organization, 1995. Environmental Health Criteria 165: Inorganic Lead. International Programme on Chemical Safety, World Health Organization, Geneva.

Zayed, J., 2001. Use of MMT in Canadian gasoline: health and environmental issues. Am. J. Ind. Med. 39, 426-433.

Zhang, G., Liu, D., He, P., 1995. Effects of manganese on learning abilities in school children. Zhonghua Yu Fang Xue Za Zhi 29, 156-158 (English abstract). 